\title{
PENERAPAN CASE-BASED REASONING PADA SISTEM CERDAS UNTUK PENDETEKSIAN DAN PENANGANAN DINI PENYAKIT SAPI
}

\author{
Irlando Moggi Prakoso ${ }^{1)}$, Wiwik Anggraeni ${ }^{2)}$ Ahmad Mukhlason ${ }^{3)}$ \\ ${ }^{1}$ Jurusan Sistem Informasi, Fakultas Teknologi Informasi, Institut Teknologi Sepuluh Nopember \\ J1. Raya ITS, Surabaya, 60111 \\ Telp : (031) 5964965, Fax : (031) 5999944 \\ E-mail : wiwik@its-sby.edu ${ }^{1)}$
}

\begin{abstract}
Cow disease causes significant impact on meat production degradation for livestock breeders. Independent early detection and treatment using intelligent system is necessary to minimalize the bad impact caused by cow disease. The former research has produced intelligent system based on Backpropagation Artificial Neural Network(ANN). But unfortunately ANN works in a blackbox because the groundwork information which lead to the diagnostic result is unshown. Intelligent system based on Cased-Based Reasoning (CBR) can solve the problem that happened in ANN based intelligent system because CBR suggests the diagnosis result based on past problems which can be revised to solve new problem accurately. Besides that, CBR can show the groundwork information from its diagnostic result. From the three experiments, using cases from case memory (scenario 1), outside case memory (scenario 2), and partial symptoms from case memory (scenario 3) gives good result with $100 \%$ and $95.83 \%$ precision value for scenario 1 and 3. And precision value which is actually true with only $59.31 \%$ for scenario 2. The poor result in scenario 2 caused by the cases used in experiment are cases that never been faced by intelligent system, so there is no cases in case memory has the same symptoms with the symptom entered in intelligent system. So it can be concluded from the experiments that this intelligent system can suggests diagnostic result accurately and eases the breeders to diagnose cow disease independently.
\end{abstract}

\section{Abstrak}

Penyakit sapi memberikan dampak signifikan terhadap penurunan produksi daging bagi para peternak sapi. Untuk meminimalisir dampak penyakit perlu dilakukan pendeteksian dan penanganan sedini mungkin secara mandiri menggunakan sistem cerdas. Penelitian sebelumnya menghasilkan sistem cerdas menggunakan algoritma Backpropagation Artificial neural Network(ANN). Namun ANN bersifat black-box karena kita tidak dapat melihat informasi yang mendasari hasil diagnosa. Sedangkan sistem cerdas berbasis Cased-Based Reasoning $(C B R)$ mampu menyelesaikan permasalahan tersebut karena CBR memberikan hasil diagnosa berdasarkan permasalahan terdahulu yang dapat direvisi untuk memecahkan permasalahan terbaru. Selain itu, ciri-ciri gejala yang mendasari hasil diagnosa juga dapat diamati. Dari ketiga uji coba dengan case didalam case memory(skenario 1), diluar case memory(skenario 2), dan gejala parsial dari case memory(skenario 3) mendapatkan hasil yang baik dengan nilai precision $100 \%$ dan $95.83 \%$ untuk skenario 1 dan 3, serta nilai precision yang memang kurang baik untuk skenario 2 sebesar 59.31\%. Hasil yang kurang baik pada skenario 2 terjadi karena case yang digunakan belum pernah ditangani oleh sistem cerdas sehingga belum ada case di case memory yang memiliki ciri-ciri gejala yang sama dengan gejala yang diinputkan. Dari hasil uji coba dapat disimpulkan bahwa sistem cerdas ini dapat memberikan hasil diagnosa yang akurat dan memudahkan peternak sapi dalam mendiagnosa secara mandiri.

Kata kunci: Case-Based Reasoning, pendeteksian penyakit sapi.

\section{PENDAHULUAN}

Daging sapi merupakan salah satu sumber daya penting yang mampu menjamin ketahanan pangan nasional. Namun produksi daging sapi lokal mengalami fluktuasi. Tahun 2005 sampai dengan 2006 terjadi peningkatan 19,2\%, lalu terjadi penurunan $18,8 \%$ pada tahun 2007 . Pada tahun 2009 produksi sapi lokal kembali mengalami peningkatan sebesar $9,1 \%$. Namun pada tahun 2007 hingga 2009, menurut Direktorat Jenderal Peternakan, pertumbuhan penyediaan daging lokal lebih rendah daripada kebutuhan yang kemudian mengakibatkan peningkatan impor untuk memenuhi kebutuhan konsumsi daging sapi. 
Prakoso, dkk., Penerapan Case-Based Reasoning pada Sistem Cerdas untuk Pendeteksian...

Dari fluktuasi produksi daging sapi tersebut, salah satu faktor penyebab penurunan produksi daging sapi disebabkan oleh faktor penyakit. Hingga saat ini peternak sapi memiliki ketergantungan yang tinggi terhadap dokter hewan untuk mendiagnosa dan melakukan penanganan penyakit sapi. Sistem cerdas merupakan salah satu alternatif yang memudahkan peternak sapi dalam mendiagnosa jenis penyakit sapi secara mandiri serta melakukan penanganan sesuai dengan anjuran yang diberikan oleh sistem cerdas.

Dalam penelitian yang telah dilakukan oleh Gusviantoko pada tahun 2011 membangun sistem cerdas menggunakan Backpropagation Artificial Neural Network (ANN) dikarenakan memiliki kemampuan untuk belajar dan dapat mengetahui hubungan tiap atribut data (Purwanto, 2011). Namun ANN memiliki kelemahan karena memerlukan jumlah data yang besar untuk tahap training dan dalam memberikan hasil diagnosis bergantung sepenuhnya terhadap data yang diolah dalam fase training (Lees, 1999). ANN juga memiliki masalah dengan overfitting karena ANN menggunakan pola dari hasil perhitungan bobot data training untuk menghasilkan hasil diagnosa (Ahn, 2009). ANN juga memiliki keterbatasan yang disebabkan adanya hidden layer sehingga ANN disebut model black-box, sehingga representasi knowledge tidak terlihat. Padahal dalam proses diagnosa penyakit diperlukan penjabaran ciri-ciri gejala yang menyertai hasil diagnosa dan dapat melakukan evaluasi apakah hasil diagnosa tersebut perlu dilakukan modifikasi atau tidak (Ellenius, 2008). Casebased Reasoning (CBR) memiliki kemampuan diagnosa berbasis kasus dan memberikan informasi secara otomatis berdasarkan pengetahuan terdahulu yang dapat direvisi untuk menyesuaikan dengan permasalahan terbaru. Sehingga pengetahuan CBR akan terus berkembang. Pemecahan masalah baru pada CBR dilakukan dengan cara mencari permasalahan sejenis di masa lampau dan memberikan solusi berdasarkan permasalahan yang paling mirip yang ada di dalam case memory. permasalahan yang dapat digunakan untuk memecahkan masalah tersimpan di dalam case memory yang dapat direvisi untuk memecahkan permasalahan di masa datang.

\section{METODOLOGI}

Pada bab ini akan dijelaskan mengenai dasar teori yang digunakan untuk melakukan penelitian. Pustaka yang digunakan adalah Casebased Reasoning, NN Matching dan SWING.

\subsection{Case-based Reasoning (CBR)}

Case-based Reasoning (CBR) adalah cara penyelesaian permasalahan baru dengan cara menggunakan kembali pengetahuan paling relevan yang telah dimiliki saat ini yang selanjutnya melakukan proses adaptasi terhadap pengetahuan tersebut untuk menyesuaikan dengan permasalahan baru. CBR merefleksikan cara kerja penyelesaian masalah manusia yang menggunakan pengetahuan yang ia miliki dalam pemecahan masalah terdahulu yang kemudian digunakan sebagai titik awal proses penyelesaian permasalahan baru yang mirip dengan permasalahan yang ia selesaikan sebelumnya (Salamó, 2010). Ilustrasi dari proses mendapatkan solusi CBR dapat dilihat pada gambar 1.

\subsection{Case-based Reasoning Cycle}

CBR melakukan proses mengingat penyelesaian masalah sebelumnya. Kemudian ketika ada permasalahan baru, CBR melakukan perbandingan antara karakteristik permasalahan baru dengan permasalahan yang pernah diselesaikan sebelumnya, ketika permasalahan terbaru mirip dengan permasalahan sebelumnya, CBR melakukan proses ekstraksi solusi dari permasalahan yang relevan dengan permasalahan baru yang dihadapi, apabila solusi tersebut sesuai maka solusi tersebut dipergunakan untuk memecahkan permasalahan baru. Setelah itu, dilanjutkan dengan proses adaptasi, yakni memperbaiki pengetahuan lama agar sesuai untuk menyelesaikan permasalahan baru. Setelah melalui proses adaptasi, pengetahuan baru akan disimpan sebagai salah satu case base. Siklus CBR dapat dilihat pada gambar 2.

\subsection{NN Matching}

NN matching dipergunakan dalam mengukur kemiripan antar case (Ahn, 2009). Penghitungan kemiripan dilakukan dengan membandingkan kemiripan atribut ke $j$ pada case (I), dan atribut ke $j$ pada case ( $i$ ) pada case memory $(R)$. Formula untuk menghitung kemiripan case input dengan case di dalam case memory terdapat pada persamaan 1 : 


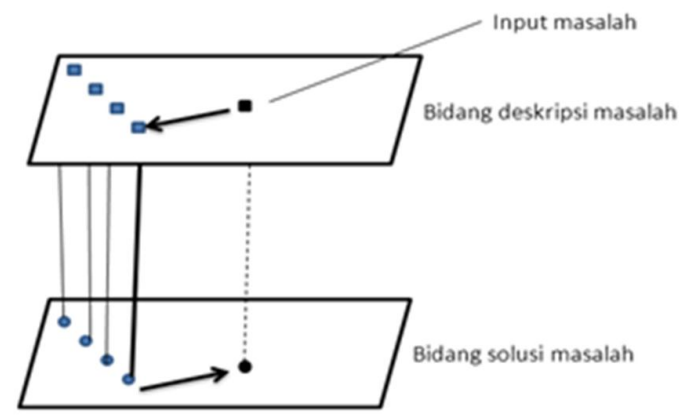

- Deskripsi dari permasalahan baru yang perlu diselesaikan

- Deskripsi dari permasalahan yang sudah terselesaikan.

- Solusi yang tersimpan

- Solusi baru yang didapatkan dari adaptasi solusi yang tersimpan

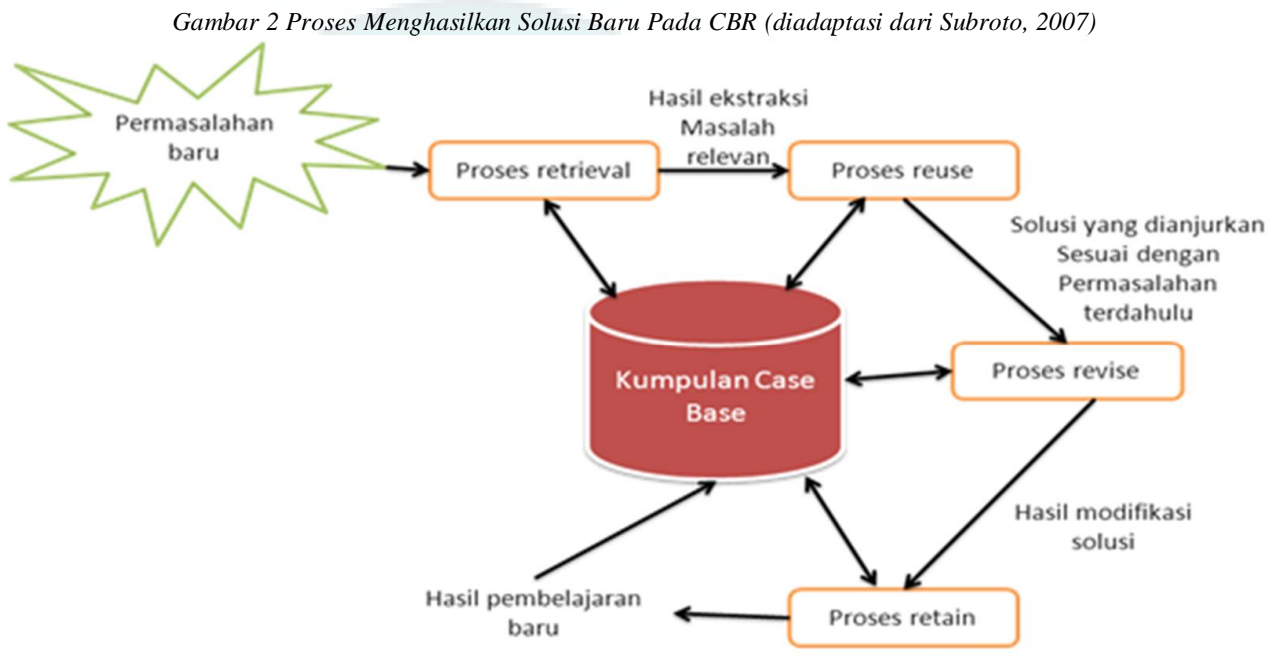

Gambar 3 Siklus CBR (diadaptasi dari Salamó \& Sánchez, 2010)

berikutnya. Nilai yang diberikan kepada seluruh atribut dinormalisasikan untuk menjadi nilai bobot yang memiliki rentang antara 0 hingga 1 (Balasubramaniam, 2007). Persamaan yang dipergunakan untuk menormalisasi nilai untuk dijadikan bobot dapat dilihat pada persamaan 2:

$j=$ atribut ke $j$

$n=$ atribut ke $n$

$W j=$ bobot atribut ke $j$.

$=$ nilai dari atribut $j$ pada case inputan $I$.

$=$ atribut $j$ pada case $i$ yang tersimpan dalam case memory $(\mathrm{R})$.

$$
=\text { hasil perbandingan }
$$

hasil

\subsection{Pembobotan SWING}

Pembobotan SWING merupakan metode yang memiliki kemampuan menggabungkan rentang atribut dari masing-masing input dari bobot dimana semua atribut didasarkan pada nilai terburuk dan nilai terbaik. Penentuan nilai dilakukan melalui penilaian yang dilakukan oleh para ahli yang diberikan dengan cara memberikan nilai maksimal pada atribut paling penting, lalu memberikan nilai dibawah nilai maksimal secara berurutan untuk atribut $\mathrm{r}_{\mathrm{i}}=$ nilai bagi atribut ke $i$

$\mathrm{w}_{i}=$ bobot $\mathrm{ke} i$

\subsection{Adaptasi Case Pada CBR}

Proses adaptasi case merupakan proses penyesuaian dari solusi yang terambil dimana solusi tersebut telah memiliki kemiripan paling tinggi. Penyesuaian dilakukan agar solusi yang terambil tersebut sesuai dengan permasalahan yang sedang dialami dan membuat pengetahuan sistem cerdas menjadi berkembang. Langkah yang dapat diambil dalam proses adaptasi sebagai berikut (Pal, 2004):

- Solusi yang dihasilkan dari case yang diambil dapat dipergunakan sebagai solusi dari permasalahan yang sedang dialami 
Prakoso, dkk., Penerapan Case-Based Reasoning pada Sistem Cerdas untuk Pendeteksian...

baik tanpa ataupun dengan melalui modifikasi.

- Ketika ternyata dari proses retrieval mendapatkan lebih dari satu kasus yang paling relevan, solusi bisa didapatkan dari salah satu kasus diantara kasus yang paling relevan.

\subsection{Pembelajaran Pada CBR}

Cara Kerja CBR sama dengan proses penalaran masalah pada otak manusia. Ketika suatu masalah atau case yang ditangani ternyata gagal, maka kegagalan akan disimpan kedalam case memory sehingga kesalahan yang sama tidak terulang. Dan ketika case baru yang ditangani ternyata sukses CBR menyimpannya kedalam case memory untuk memecahkan permasalahan yang sama di kemudian hari. Untuk mengetahui case yang sukses atau gagal perlu dilakukan penilaian dalam dunia nyata untuk memastikan solusi dari CBR benar-benar sukses atau gagal (Iqbal, 2006).

\subsection{Pemeliharaan Case-based}

Pemeliharaan dengan mengurangi duplikasi case dan menghapus atau memperbaiki case yang salah merupakan hal yang penting untuk mencegah level error terlalu tinggi. Pemeliharaan case-based memberikan pengaruh positif pada kualitas case tersimpan untuk memberikan solusi pada permasalahan yang akan datang. Karena semakin banyaknya jumlah case yang tersimpan, performa pencarian case juga semakin menurun (Subroto, 2007).

\section{HASIL dan PEMBAHASAN}

\subsection{Algoritma CBR untuk Diagnosa Penyakit Sapi}

Sistem cerdas berbasis CBR ini merupakan sebuah aplikasi berbasis web yang berfungsi untuk melakukan diagnosa penyakit sapi berdasarkan ciri-ciri yang diinputkan oleh pengguna.

Pengguna menginputkan ciri-ciri gejala pada form input. Ciri-ciri yang dimasukkan tersebut akan dibandingkan dengan ciri-ciri gejala yang tersimpan di dalam case memory. Dari hasil perbandingan tersebut akan dihitung nilai kemiripan dan ditampilkan case yang memiliki kemiripan tertinggi. Gambar 3 menampilkan algoritma CBR untuk diagnosa penyakit sapi.
Langkah-langkah pada algoritma CBR adalah sebagai berikut:

1. Pengguna menginputkan gejala penyakit pada sistem cerdas.

2. Sistem cerdas menghitung kemiripan antara case yang diinputkan dengan case pada case memory menggunakan $N N$ matching.

3. Sistem cerdas menampilkan case paling mirip beserta hasil diagnosa berdasarkan tingkat kemiripan tertinggi.

4. Pengguna mengecek kebenaran hasil diagnosa di dunia nyata dan mengonfirmasi kebenaran hasil diagnosa. Jika hasil benar, proses berlanjut pada langkah (5). Jika hasil diagnosa salah maka case dan hasil diagnosa tersebut akan ditandai dan dilanjutkan pada proses (7)

5. Jika hasil diagnosa benar, hasil diagnosa yang diusulkan tersebut dipasangkan dengan case yang baru diinputkan pengguna. Namun belum disimpan kedalam case memory.

6. Sistem cerdas memeriksa apakah kombinasi case yang dinputkan, dan diagnosa yang diusulkan sudah ada di dalam case memory. Jika sudah ada, kombinasi case dan solusi tersebut tidak disimpan. Namun jika belum ada lanjut pada proses (9) \& (10).

7. Case beserta hasil diagnosa yang dilaporkan salah dan telah ditandai akan diperbaiki oleh pakar.

8. Setelah case dan usulan solusi diperbaiki, apabila case tersebut memiliki kemiripan identik maka langsung masuk proses (10), namun jika tidak identik maka masuk pada proses(9) dilanjutkan dengan proses (10).

9. Menyisipkan ID baru pada case yang tidak terdapat dalam case memory.

10. Melakukan proses penyimpanan case \& solusi kedalam database.

\subsection{Arsitektur Perangkat Lunak Sistem Cerdas}

Sistem cerdas ini dibuat menggunakan bahasa pemrograman PHP dengan framework Codeigniter 1.7.2. Framework Codeigniter berbasis MVC (Model, View, Controller) yang memberikan kemudahan dalam memanajemen konektivitas dan fleksibilitas antar fungsi. Pola MVC membuat sistem cerdas memiliki tiga lapisan yaitu model, yang berhubungan dengan sistem manajemen basis data yang dibutuhkan oleh sistem cerdas. 
Jurnal Sistem Informasi, Volume 4, Nomor 5, September 2013, hlm 360-368

(5)

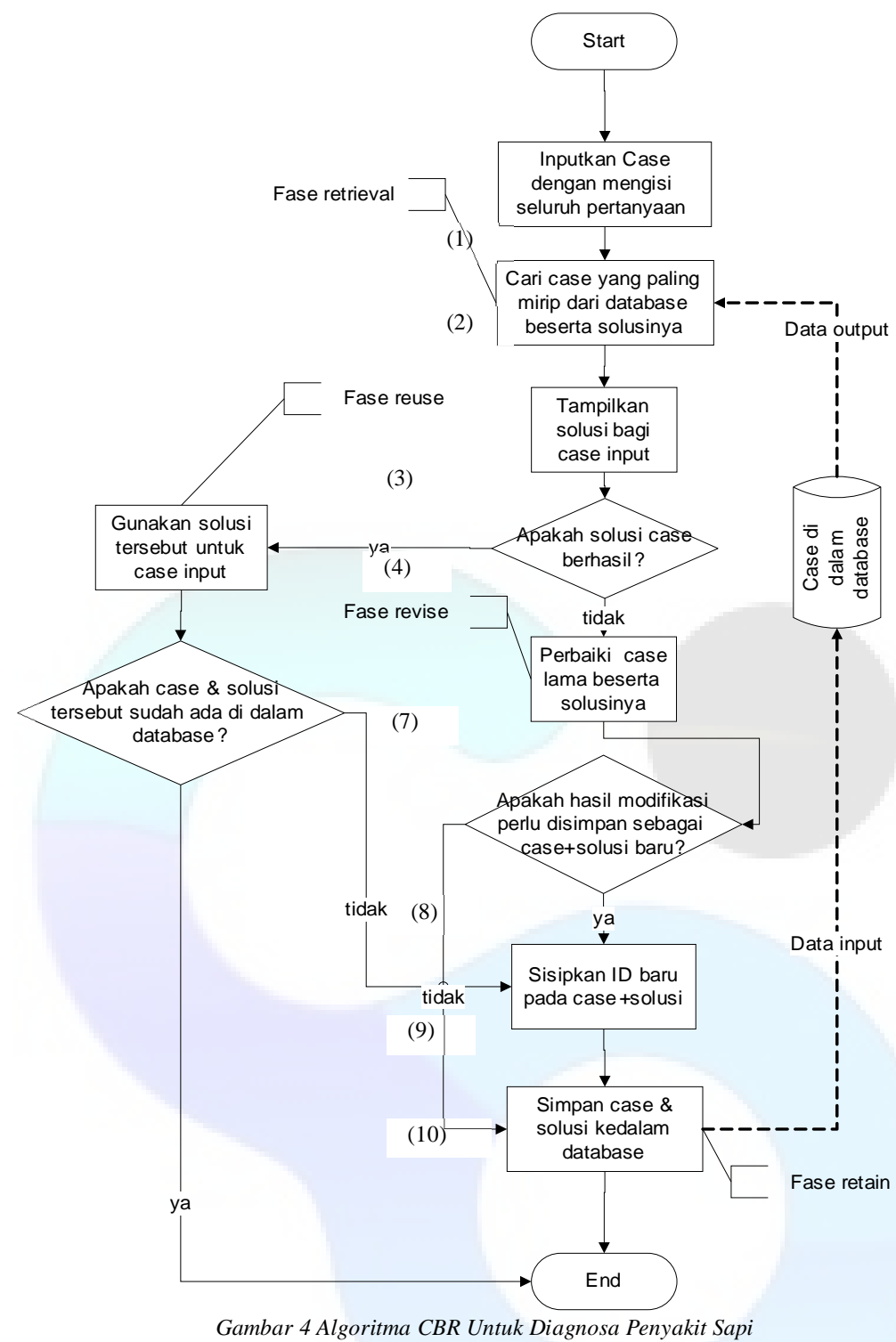

(2) input Gejala A Atur Bobot Koreksi Kesalahan Diagnosa \&user Area

Hasil Diagnosa \& Solusi

\section{Hasi1 Diagnosa}

Berdasarkan gejala penyakit yang anda inputkan, dapat disimpulkan bahwa sap anda

Penyakit Mulut Kuku

asal diagnosa

\section{Solusi}

Berdasarkan jenis penyakit, penanganan yang dapat dilakukan antara lain

sapi yang terjangkit Penyakit Mulut Kuku

dibunuh, lalu dibakar atau dikubur, sebisa mungkin sapi yang terjangkit Penyakit Mulut Kuku tidak berada dekat atau berinteraksi dengan sapi yang sehat. sapi yang berada dalam radius $5 \mathrm{~km}$ dari sapi yang terjangkit

Penyakit Mulut Kuku juga harus dimusnahkan. untuk keterangan lebih lanjut hubungi dokter hewan.
Konfirmasi

Kelayakan Hasil

Diagnosa

Apakah hasil diagnosa \& solusi benar?

- Benar O Salah Kirim

Gambar 4. Antarmuka Hasil Diagnosa \& Solusi Beserta Konfirmasi Kelayakan Hasil Diagnosa 


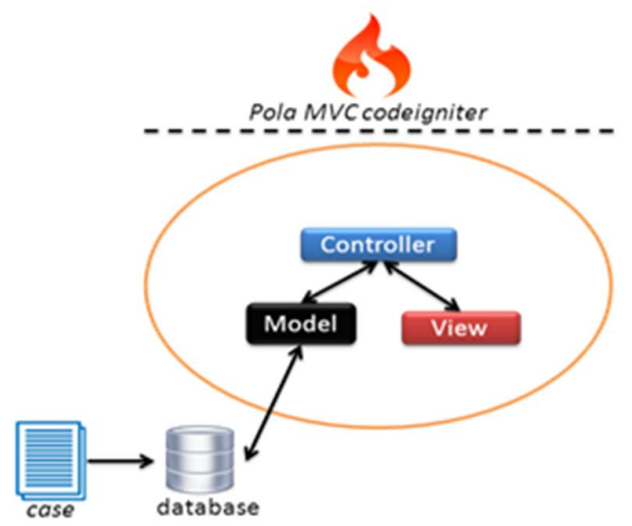

Gambar 5. Arsitektur Perangkat Lunak Sistem Cerdas

View yang merupakan lapisan presentasi aplikasi yang menampilkan antarmuka dan masukan dari pengguna. Serta controller yang merupakan lapisan logika yang menjadi penghubung antara view dan controller yang menangani semua proses logis seperti menampilkan informasi ke lapisan presentasi hingga menghubungi lapisan manajemen basis data. Arsitektur perangkat lunak sistem cerdas dapat dilihat pada Gambar 5.

\subsection{Implementasi pada Fase Retrieval}

Pengguna dapat memasukkan gejala penyakit sapi pada seluruh formulir input pada sistem cerdas kemudian memilih tombol Cari. Antarmuka formulir input dapat dilihat pada gambar 6. Setelah itu hasil diagnosa dan solusi penanganan dini ditampilkan pada antarmuka hasil diagnosa dan solusi yang dapat dilihat pada gambar 4. Pada antarmuka tersebut pengguna dapat mengetahui penyakit apa yang menyerang penyakit sapi, beserta solusi penanganan dini.

\subsection{Implementasi pada Fase Reuse}

Setelah sistem cerdas menampilkan antarmuka hasil diagnosa dan solusi beserta konfirmasi kelayakan hasil diagnosa (Gambar 4). Pengguna mengkonfirmasi apakah hasil dari diagnosa atau solusi penanganan dini tersebut benar kemudian memilih tombol kirim. Sistem akan menyimpan case tersebut dengan solusi yang diusulkan dan akan disimpan sebagai case baru apabila tidak ada case yang identik dengan case tersebut, sekaligus mencatat konfirmasi pengguna yang menyatakan case dan solusi tersebut benar atau salah. Setelah itu, sistem cerdas menampilkan pemberitahuan bahwa konfirmasi telah dilaporkan yang ditunjukkan pada gambar 9 .

\subsection{Implementasi pada Fase Revise}

Dokter hewan dapat melihat daftar case yang dilaporkan salah oleh pengguna. Pada antarmuka tersebut, dokter hewan juga dapat menghapus case yang perlu dihapus sekaligus dapat melihat detail informasi dari case yang dapat direvisi untuk memperbaharui informasi dari case tersebut (Gambar 7).

\subsection{Implementasi pada Fase Retain}

Fase retain merupakan fase yang berperan pada manajemen knowledge. Diantaranya proses penyimpanan case yang telah dikoreksi kedalam case memory untuk memecahkan permasalahan pada masa yang akan datang. Beberapa hal yang terjadi pada fase ini antara lain mengintegrasikan case baru kedalam case memory, serta mengupdate case lama beserta solusinya di case memory.

\subsection{Pengujian dan Evaluasi}

Pengujian sistem cerdas berbasis CBR dilakukan dengan tiga skenario pengujian yang dijabarkan sebagai berikut :

1. Pengujian menggunakan case yang telah ada di dalam case memory.

2. Pengujian menggunakan case yang belum ada case memory.

3. Pengujian menggunakan case dengan gejala parsial dari case memory.

Ketiga skenario pengujian tersebut bertujuan untuk mengetahui kemampuan sistem cerdas dalam memberikan hasil diagnosa yang akurat ketika sistem cerdas menghadapi situasi dimana case yang dimasukkan sudah ada di case memory, case yang dimasukkan belum ada di case memory, maupun case yang dimasukkan memiliki kesamaan secara parsial dengan case yang terdapat di case memory. Pengujian pada ketiga skenario dilakukan menggunakan 20 case dimana 5 case memiliki hasil diagnosa sehat, 5 case memiliki hasil diagnosa Penyakti Mulut $\mathrm{Kuku}, 5$ case memiliki hasil diagnosa Mastitis, dan 5 case memiliki hasil diagnosa Septisemia Epzootica.

Case uji coba tersebut dimasukkan kedalam sistem cerdas dan dicatat hasil diagnosa yang muncul. Hal ini dilakukan pada keseluruhan case uji coba, dilanjutkan dengan perhitungan nilai precision, recall, serta accuracy pada masing-masing skenario uji coba. 


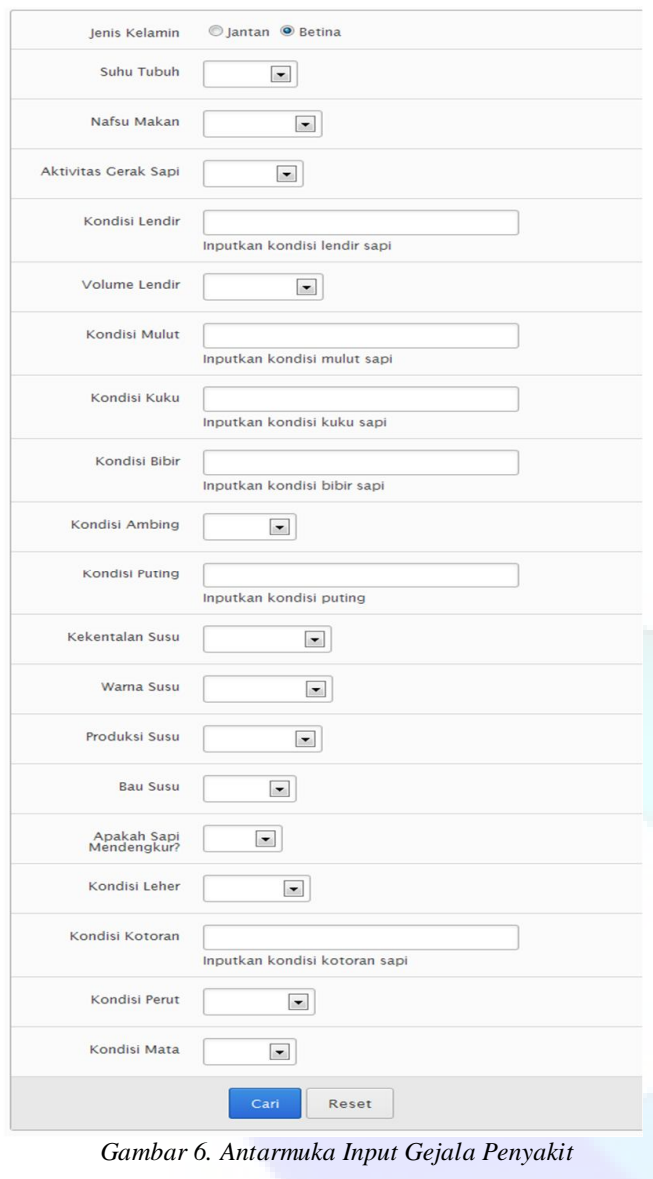

Pengujian untuk semua skenario akan diujikan sebanyak 4 kali dengan rincian sebagai berikut :

1. Melakukan uji coba dengan hasil diagnosa sehat sebagai kelas positif.

2. Melakukan uji coba dengan hasil diagnosa penyakit mulut kuku sebagai kelas positif.

3. Melakukan uji coba dengan hasil diagnosa Mastitis sebagai kelas positif.

4. Melakukan uji coba dengan hasil diagnosa Septisemia Epzootica sebagai kelas positif.

Setelah melakukan 4 kali pengujian pada ketiga skenario, dilanjutkan dengan menghitung nilai precision, recall, dan accuracy yang dapat dilihat pada tabel 1. Sedangkan perbandingan precision, recall, accuracy dari ketiga skenario secara grafis dapat dilihat pada gambar 8 .

Pada gambar 8 dapat dilihat bahwa pada skenario 1 memiliki hasil precision, recall, dan accuracy yang paling tinggi dan skenario 3 memiliki hasil sedikit lebih rendah dibandingkan dengan skenario 1. Sedangkan skenario 2 memiliki precision, recall, dan accuracy yang paling rendah dan kurang baik.

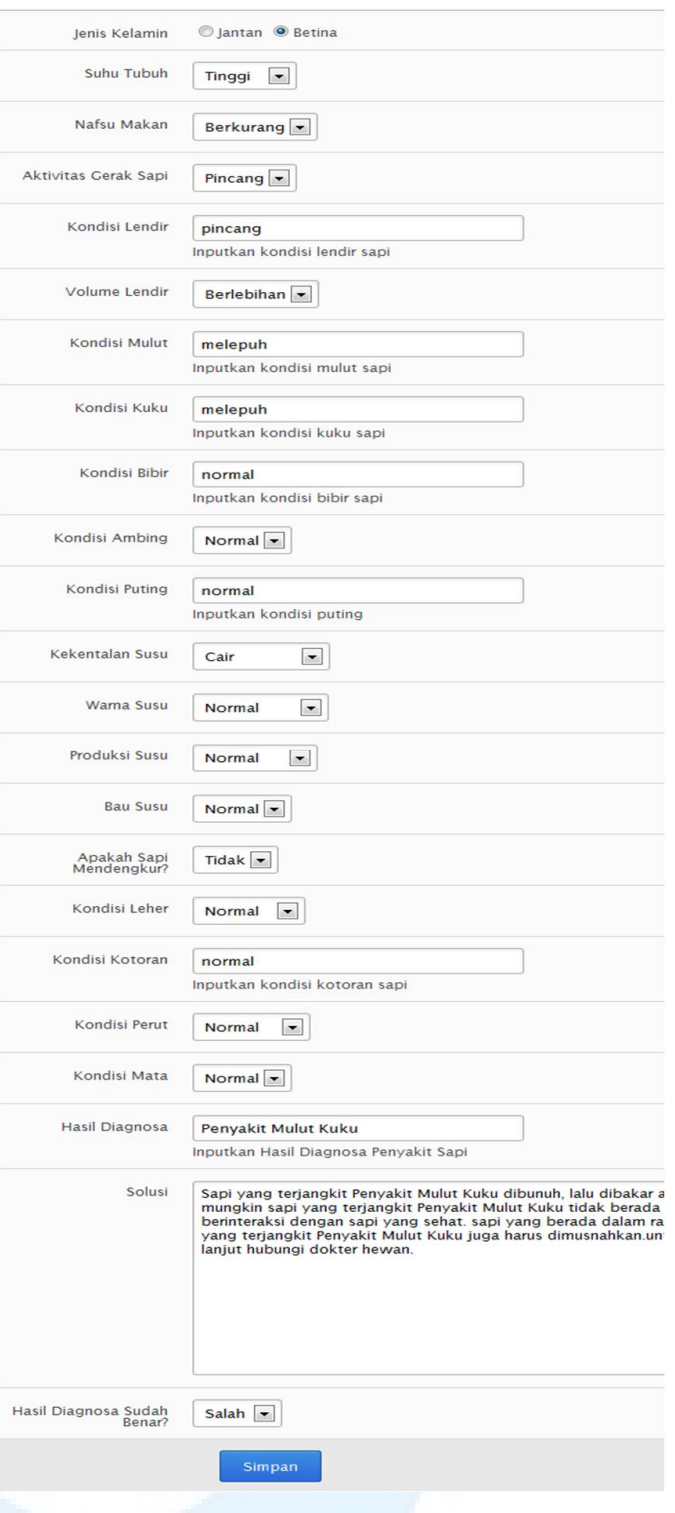

Gambar 7. Antarmuka Edit Case.

Tabel 1. Hasil Precision, Recall, Dan Accuracy pada Ketiga Skenario Uji Coba

\begin{tabular}{llcc}
\hline Skenario & Precision & Recall & Accuracy \\
\hline Skenario 1 & $100 \%$ & $100 \%$ & $100 \%$ \\
Skenario 2 & $59.31 \%$ & $40.00 \%$ & $71.25 \%$ \\
Skenario 3 & $95.83 \%$ & $95 \%$ & $97.5 \%$ \\
\hline
\end{tabular}

Hal ini menunjukkan bahwa CBR memiliki kinerja yang baik dalam memberikan diagnosa yang akurat, baik ketika menyelesaikan permasalahan dengan ciri identik maupun menyelesaikan permasalahan dengan ciri yang sebagian sama dengan case yang telah ada di dalam case memory, Sedangkan untuk ciri yang berbeda dengan case yang ada di dalam case memory, sistem cerdas kurang dapat memberikan hasil diagnosa dan solusi yang akurat. 


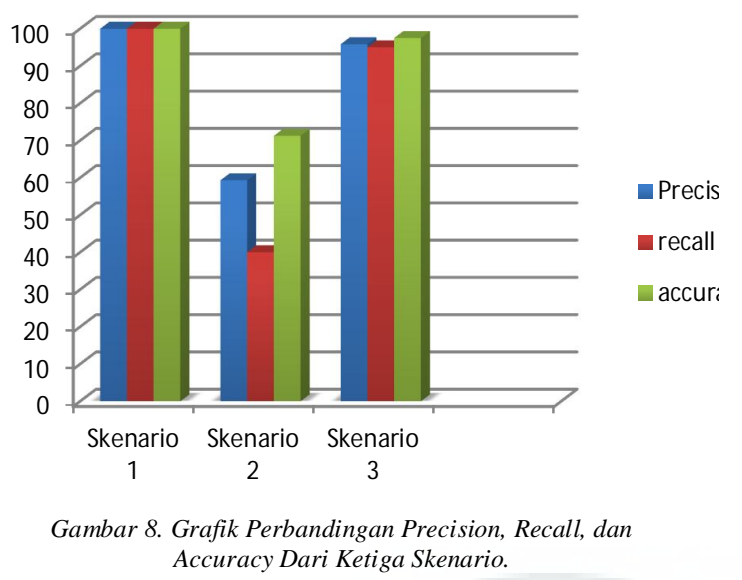

\section{SIMPULAN dan SARAN}

Setelah uji coba menggunakan tiga skenario dengan menggunakan masing-masing 20 data uji coba dari case memory, diluar case memory, dan data yang memiliki kemiripan gejala parsial dari case memory. Dilanjutkan dengan perhitungan nilai precision, recall dan accuracy untuk masing-masing skenario, kesimpulan yang dapat diambil adalah sebagai berikut :

1. Berdasarkan hasil pada skenario 1 , dengan mengujikan kembali case yang sudah terdapat di dalam case memory memiliki hasil precision, recall, dan accuracy yang sangat tinggi yakni nilai precision $100 \%$, recall $100 \%$, dan accuracy $100 \%$. Hal ini menunjukkan bahwa sistem cerdas berbasis CBR mampu memberikan hasil diagnosa dengan sangat baik ketika sistem cerdas pernah menyelesaikan permasalahan yang sama sebelumnya, sehingga sistem cerdas hanya perlu memanggil kembali case dan solusi telah tersimpan di dalam case memory.

2. Hasil yang didapatkan dari skenario 2, dengan mengujikan case-case yang tidak terdapat pada case memory memiliki hasil precision, recall, dan accuracy yang kurang baik yaitu nilai precision $59.31 \%$, recall $40.00 \%$, dan accuracy $71.25 \%$. Ternyata sistem cerdas berbasis CBR memang kurang mampu memberikan hasil diagnosa yang akurat ketika sistem cerdas sebelumnya belum pernah menangani permasalahan yang diinputkan, sehingga case beserta solusi yang diusulkan dari case memory memiliki kemungkinan tidak relevan yang lebih besar. Hal ini dapat diatasi dengan memperkaya variasi case di dalam case memory.
3. Berdasarkan hasil yang didapatkan dari skenario 3, yakni dengan mengujikan case dengan gejala parsial dari case memory memiliki nilai nilai precision $95.83 \%$, recall $95 \%$, dan accuracy $97.5 \%$. Hal ini menunjukkan bahwa sistem cerdas berbasis CBR masih mampu memberikan hasil diagnosa dengan benar meskipun permasalahan yang diinputkan memiliki kemiripan hanya pada sebagian gejala dengan case yang tersimpan di dalam case memory.

4. Berdasarkan hasil percobaan skenario $1 \& 3$ menunjukkan bahwa semakin banyak jumlah atribut gejala yang sama antara case yang diinputkan kedalam sistem cerdas dengan case yang tersimpan di case memory dapat meningkatkan kinerja sistem cerdas dalam memberikan hasil diagnosa dan solusi dengan tepat.

5. Dalam studi kasus ini, berdasarkan hasil uji coba dari ketiga skenario menunjukkan bahwa semakin banyak jumlah case yang tersimpan di case memory dapat meningkatkan ketepatan hasil diagnosa secara signifikan, karena semakin banyak case tersimpan di case memory menunjukkan bahwa sistem cerdas telah memiliki banyak pengalaman dalam menangani berbagai kasus, sehingga kemungkinan kebenaran case dan solusi yang disarankan oleh sistem cerdas menjadi lebih tinggi.

Sistem cerdas berbasis CBR pada studi kasus ini tidak dapat mempertahankan case yang berguna dan menghapus case yang tidak berguna secara otomatis. Selain itu juga tidak mampu menghitung kemiripan antar case ketika menghadapi kata-kata berupa sinonim. Oleh karena itu, saran yang dapat dipertimbangkan untuk pengembangan selanjutnya :

1. Mengembangkan sistem cerdas berbasis Adaptive Case Based Reasoning yang memiliki kemampuan untuk mempertahankan case yang berguna dan menghapus case-case yang salah secara otomatis untuk meningkatkan efektifitas pemeliharaan case sehingga fase retrieval menjadi lebih cepat dan efisien.

2. Mengembangkan sistem cerdas baik berbasis CBR atau Adaptive CBR yang mampu menghitung kemiripan antar case walaupun deskripsi gejala penyakit yang diinputkan merupakan sinonim dari deskripsi gejala penyakit yang tersimpan di case memory. 


\section{DAFTAR RUJUKAN}

Ahn, H., \& Kim, K.-j., 2009. Bankruptcy Prediction Modeling With Hybrid Casebased Reasoning and Genetic Algorithms Approach. Applied Soft Computing, 9 (2),pp.599-607.

Balasubramaniam, A., Boyle, R, A., \& Voulvoulis, N., 2007. Improving Petroleum Contaminated Land Remediation. Chemosphere, 66 (5),pp.791-798.

Direktorat Jenderal Peternakan. ,2010. Blue Print Program Swasembada Daging Sapi 2014. Jakarta: Kementrian Pertanian.

Ellenius, J., \& Groth, T., 2008. Dynamic Decision Support Graph_-Visualization of ANN-Generated Diagnostic Indications of Pathological Conditions Developing Over Time. Artificial Intelligence in Medicine, 42 (3),pp.189-198.

Iqbal, N., \& Ashraf, M. H. 2006. Evaluation of jCOLIBRI. Master. Vasteras: Malardalen University.
Lees, B., \& Corchado, J., 1999. Integrated CaseBased Neural Network Approach to Problem Solving. In: 5th Biannual German Conference on Knowledge-Based Systems: Knowledge-Based Systems - Survey and Future Directions, Würzburg. Germany 3-5 March 1999. Springer: London.

Pal, S., 2004. Foundations of Soft Case-Based Reasoning. Hoboken: Wiley-Interscience publication.

Purwanto, G, D., 2011. Penerapan Algoritma Artificial Neural Network Pada Sistem Cerdas Untuk Pendeteksian dan Penanganan Dini Penyakit Sapi. Sarjana. Surabaya: Institut Teknologi Sepuluh Nopember

Salamó, M., \& Sánchez, M,L., 2010. Adaptive Case-based Reasoning Using Retention And Forgetting Strategies. KnowledgeBased Systems , 24 (2),pp.230-247.

Subroto, I, M., 2007. Case-based Retrieval On Question Items Generation. Master. Kuala Lumpur: Universiti Teknologi Malaysia. 